\title{
Analysis of Microbiological and Physiochemical Properties of Top Soil from Municipal Dumpsites in Benin City
}

\author{
*11OSHOMA, CE; ${ }^{2}$ IGBETA, B; ${ }^{1}$ OMONIGHO, SE \\ ${ }^{I}$ Department of Microbiology, University of Benin, Benin City, Nigeria \\ ${ }^{2}$ Medical Laboratory, Lonia Clinic and Maternity Ovwian Delta State \\ *Corresponding author email: cyprian.oshoma@uniben.edu
}

\begin{abstract}
The effect of disposing municipal waste on soil was evaluated by analyzing the microbiological and enzyme activity of soil samples at three different locations, from five municipal waste dumpsites and compared with soil samples from a farmland which serves as the control. Soil microbial load, physicochemical parameters and enzyme

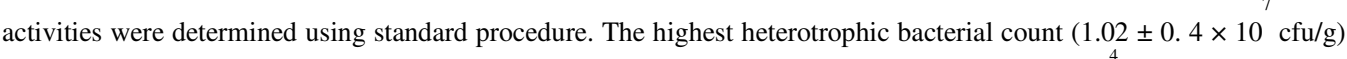
was recorded from New Benin market Dumpsite (sampling point A) while the least $(3.25 \pm 0.4 \times 10 \mathrm{cfu} / \mathrm{g}$ ) was from the control (sampling point $\mathrm{C}$ ). The result obtained showed that there was significant difference $(\mathrm{p}>0.05)$ in the Heterotrophic bacteria and fungi count between the control and the soil samples from the various locations of the dumpsites. The bacteria identified were Acinetobacter species, Micrococcus luetus, Pseudomonas aeruginosa, Serratia species, Bacillus subtilis, Klebsiella species, Staphylococcus aureus, Arthrobacter species, Escherichia coli and Streptococcus feacalis, while fungi identified were Aspergillus niger, Trichoderma species, Penicillium species, Fusarium species, Mucor species, Saccharomyces species, Rhizopus species. Pseudomonas aeruginosa was the most prevalent bacterial isolate $(20.3 \%)$ while Streptococcus feacalis was the least isolate $(3.1 \%)$. Aspergillus niger was the most prevalent fungi isolate and Fusarium species the least isolated fungi. The enzymatic profile revealed that Oba market and Satana market had the highest Dehydrogenase and Urease activities with the values of $23.70 \pm 16.32$ $\mathrm{mg} / \mathrm{g} / 6 \mathrm{~h}$ and $97.90 \pm 14.93 \mathrm{mg} / \mathrm{g} / 24 \mathrm{~h}$ respectively. The physicochemical parameter measured in this study showed that the soil samples were acidic $(5.60 \pm 0.17-6.23 \pm 0.35)$ and sandy $(72.20 \pm 4.11-90.60 \pm 0.00 \%)$. Trace amount of zinc $(0.10 \pm 0.00-1.53 \pm 1.02 \mathrm{mg} / \mathrm{kg})$, lead $(<0.01-1.23 \pm 0.17 \mathrm{mg} / \mathrm{kg})$ and copper $(0.01 \pm 0.00-0.80 \pm 0.10 \mathrm{mg} / \mathrm{kg})$ was observed in both the control soil and the test samples. The result showed that although municipal waste dump is an unsustainable practice, it has a positive impact on the quality of the soil samples examined. (C) JASEM
\end{abstract}

https://dx.doi.org/10.4314/jasem.v21i5.28

Key Words: Microbiological, Enzymatic, Municipal Waste Dumpsites, Soil, Benin City.

Soil is a critically important component of the earth's biosphere, functioning not only in the production of food and fiber but also in the maintenance of local, regional and global environmental quality (Glanz, 1995). Increasing human populations, decreasing resources, social instability, and environmental degradation pose serious threats to the natural processes that sustain the global ecosphere and life on earth (Constanza et al., 1992). Of the many problems associated with urbanization especially in sub-Sahara Africa, waste management crisis has assumed an important position. Today, waste disposal has become an acute problem in numerous urban centers across Africa (Pasquini and Harris, 2005), with formal waste collection ranging from 11 to $44 \%$ for households in cities such as Accra, kinshasha, Lagos, Kaduna and Enugu (Pasquini and Harris, 2005). Nigeria has an enormous waste management problem, all over the country; there are examples of unsanitary open dumps and industrial contaminations which are continuously discharged on land and into streams and rivers without treatment (Agunwamba, 1998).

Dumpsite is a traditional way of waste disposal same with landfill method for managing waste. Dumpsites are mostly established in disused mining quarries or excavated pits far away from residential settlement. Designated agency, corporate bodies and individuals routinely collect waste into these dumpsites (AbdulsSalam, 2009). In Nigeria, modern landfill facilities are not easily found, therefore waste sorting-out into degradable, non-degradable and recyclable may not be achieved (Osazee et al., 2013). Poor waste dumpsites management could create adverse environmental impacts such as wind-blown litter, attraction of rodent and pollutant for example leachates that can contaminate underground soil bed or aquifer (Abduls-Salam, 2009).

The microorganisms found in waste dumpsites obtain their nutritional requirements from the waste constituents, thus aiding the detoxification of complex organic molecules (Osazee et al., 2013). However, some solid waste can also contain large amount of organic pollutants that can persist in the environment (Williams and Hakem, 2016). One of the major concerns for the indiscriminate dumping of waste is the closeness of these dumpsites to residential buildings, thus becoming a public threat. Soil enzymes are the mediator's and catalyst of important soil functions such as decomposition of 
organic inputs, transformation of native soil organic matter, detoxification of xenobiotic (Dick, 1997). Soil enzymology is nowadays of practical importance as changes in soil management and land use such as xenobiotic pollution, agriculture, de-vegetation and revegetation are reflected in the soil enzyme activity and can anticipate changes in soil quality before they are detected by other soil analyses (Utobo and Tewari, 2015). Also the use of soil enzyme in the evaluation of soil quality has become a more valuable tool since culturable and unculturable, even extracellular and intracellular enzyme activities are estimated in the process.(Leo et al., 2014). The objective of this investigation was to assess the microbial population and physicochemical quality of soil from municipal dumpsites found in Benin City. Also, an attempt was made to assess the enzymatic activities of soil microbes from the dumpsites.

\section{MATERIALS AND METHODS}

Study Area: This study was conducted in Benin City Edo State, Nigeria. Soil samples were collected from three locations from five different dumpsites namely Ediaken market, Oba market, New Benin market, Ekiosa market and Satana market.

Collection and Preparation of Soil Sample for Analysis: Top soil was collected from the five dumpsites at a depth of $1 \mathrm{~cm}-10 \mathrm{~cm}$ with the aid of a soil auger. Prior to collection of soil sample, surface debris and other plant materials were removed from the soil by hand picking. Soils were sampled at three (3) different points in the dumpsite viz the middle labelled as A, 50 meters to the west as B and 50 meters to the east from the middle as $\mathrm{C}$. Control sample was also collected in like manner from a fallow farmland at Ugbowo, Benin City.

Isolation and Enumeration of Soil Heterotrophic Microflora: Microbial enumeration was carried out by weighing ten grams (10 g) of the soil samples using an analytical balance (Metter weighing balance PB3002 Switzerland) and mixing with 90ml of sterile distilled water to form the stock suspension. Serial dilution (10-fold) of the soil sample was carried out. From the dilution, $1 \mathrm{ml}$ was then plated out by pour plate method on nutrient agar for bacterial count and potato dextrose agar for fungal count. The Nutrient agar plates were incubated at $37{ }^{\circ} \mathrm{C}$ for $24 \mathrm{~h}$. and while PDA plates were at $28 \pm 2{ }^{\circ} \mathrm{C}$ for $72 \mathrm{~h}$. After incubation discrete colonies of culture on nutrient agar and potato dextrose agar plates were counted and the unit expressed in cfu/g. Bacteria identification was performed using the keys provided in the scheme of Holt et al. (1994) while Fungal isolates were examined macroscopically and microscopically using the needle mounts technique. Their identification was performed according to the scheme of Larone (1986).

Assay for soil enzyme activity: The soil enzyme analysis carried out in the investigation were dehydrogenase, urease, peroxidase, catalase, acid and alkaline phosphatase. Soil dehydrogenase was determined by methods describe by Cassida et al. (1964). Urease was estimated using colorimetric methods while Peroxidase activity was estimated using $\mathrm{KMnO}_{4}$ titration method (Alef and Nannipieri 1995). Catalase activity was estimated by back titration of residual hydrogen peroxide $\left(\mathrm{H}_{2} \mathrm{O}_{2}\right)$ with Potassium Permanganate $\left(\mathrm{KMNO}_{4}\right)$. The method described by Tabatabai (1997) was used to determine acid and alkaline phosphatase.

Determination of soil samples physicochemical properties: The respective soil samples were placed on large wooden tray and air-dried for $72 \mathrm{~h}$. Lumps of moist soil samples were broken by hand prior to air drying of the samples. The air dried samples were sieved using a $2 \mathrm{~mm}$ mesh. Parameters which included soil $\mathrm{pH}$ and electrical conductivity were ascertained using procedures described by Kalra and Maynard (1991). Particle Size Distribution, Total Organic Carbon and Phosphorus were determined by method describe by Onyeonwu (2000). Also, metals such as Sodium (Na), Potassium (K), Calcium (Ca) and Magnesium (Mg) were determined according to methods stated by Radojevic and Bashkin, (1999). Trace metals Zinc ( $\mathrm{Zn})$, Iron (Fe), Lead ( $\mathrm{Pb})$, Copper $(\mathrm{Cu})$, and Cadmium $(\mathrm{Cd})$ content of the soil samples were evaluated in accordance with procedures stated by Onyeonwu (2000) using a Digester and Atomic Absorbance Spectrophotometer (AAS).

\section{RESULT AND DISCUSSION}

Healthy state of a soil is the continuous ability of the soil to function as a vital living system, in the ecosystem, thus sustaining biological productivity and promoting the quality of water and air environment so as to maintain plant, animal and human health (Pankhurst et al., 1997). The quality of soil depend more on the natural composition and changes caused by human use and management (Pierce and Larson, 1993), also the physicochemical properties of the soil (Grantina et al., 2011). Despite the observed dumping of waste materials on the top soils by individuals at different sites, varying microbial load was recorded from the receiving soil. This is a reflection that the waste materials on the soil 
had no detrimental impacts on the growth and proliferation of the soil micro-flora (Osazee et al., 2013). The heterotrophic bacterial counts for the various Dumpsite the soil samples are shown in Table 1. Dumpsite from New Benin market (sampling point A) had the highest heterotrophic bacterial count $(1.02 \pm 0.4 \times 10 \mathrm{cfu} / \mathrm{g})$ while the least $\left(3.25 \pm 0.4 \times 10^{4} \mathrm{cfu} / \mathrm{g}\right)$ was from the control (sampling point $\mathrm{C}$ ). The bacterial load recovered from the control soil was comparatively lesser than soils collected from all the markets dumpsites. This trend is collaborated by the higher organic carbon and nitrogen content of the dumpsite soils in comparison to the control soil. This might be the result of the increased availability of biodegradable organic and inorganic substrates from the variety of municipal wastes continuously being dumped at these sites. The highest heterotrophic fungi count $(3.20 \pm$ $0.3 \times 10^{4} \mathrm{cfu} / \mathrm{g}$ ) was recorded from the control sampling point A while Ekiosa market sampling point $\mathrm{A}\left(3.00 \pm 0.8 \times 10^{2} \mathrm{cfu} / \mathrm{g}\right)$ had the least count (Table 2). The high fungi counts observed in the control soil sample could be as a result of complex substrates of plant origin present on the farm land (Thorn and Lynch, 2007).

The result indicated the presence of ten genera of bacteria namely Acinetobacter species, Micrococcus lutus, Pseudomonas aeruginosa, Serratia species,
Bacillus subtilis, Klebsiella species, Staphylococcus aureus, Arthrobacter species, Escherichia coli and Streptococcus feacalis, while seven genera of fungi was identified these includes Aspergillus niger, Trichodermal species, Penicillium species, Fusarium species, Mucor species, Saccharomyces species, Rhizopus species. Of the bacterial isolated, Pseudomonas aeruginosa was the most prevalent isolate occurring at all the sample collection site with a percentage frequency of $20.3 \%$ while streptococcal feacalis were the least isolated isolate occurring only in three dumpsites with a percentage frequency of $3.1 \%$. Aspergillus niger was the most prevalent fungi isolate occurring in all the sample collection sites with a percentage frequency of $22.4 \%$ while Fusarium species was the least isolated fungi from the soil samples occurring only at three sample collection sites with a percentage frequency of $8 \%$. The microorganisms found in these waste Dumpsites derived their nutritional requirement from the waste hence the high bacterial growth profile (Osazee et al., 2013). One of the major concerns for the indiscriminate dumping of waste to most site is the closeness of these dumpsites to residential buildings that will lead to environmental risk (Agunwamba, 1998). The microbial isolates identified from the soil samples (Table 3 and 4), have been reported to be associated with wastes and waste biodegradation (Obire et al., 2002).
Table 1: Heterotrophic bacterial count (cfu/g) of soil samples from the various sampling point at the dumpsites designated as $\mathrm{A}$ at the middle, B 50 meters to the west and $\mathrm{C} 50$ meters to the east from the middle, and control. Values are means double replicates \pm

\begin{tabular}{llll}
\multicolumn{4}{c}{ standard deviations. } \\
\hline Sample & $\mathrm{A}$ & $\mathrm{B}$ & $\mathrm{C}$ \\
\hline Control & $4.0 \pm 0.4 \times 10^{4}$ & $3.8 \pm 0.4 \times 10^{4}$ & $3.3 \pm 0.4 \times 10^{4}$ \\
Edaiken Market & $8.7 \pm 0.5 \times 10^{6}$ & $8.1 \pm 0.9 \times 10^{4}$ & $7.5 \pm 0.4 \times 10^{4}$ \\
Oba Market & $6.6 \pm 0.6 \times 10^{6}$ & $4.1 \pm 0.3 \times 10^{4}$ & $6.6 \pm 0.6 \times 10^{4}$ \\
New Benin Market & $1.0 \pm 0.4 \times 10^{7}$ & $7.7 \pm 0.6 \times 10^{4}$ & $6.7 \pm 0.5 \times 10^{4}$ \\
Satana Market & $3.6 \pm 0.4 \times 10^{6}$ & $9.6 \pm 0.5 \times 10^{4}$ & $5.6 \pm 0.6 \times 10^{4}$ \\
Ekiosa Market & $5.6 \pm 0.6 \times 10^{6}$ & $5.0 \pm 0.1 \times 10^{4}$ & $7.7 \pm 0.4 \times 10^{4}$ \\
\hline
\end{tabular}

Table 2: Heterotrophic fungi count (cfu/g) of soil samples the various sampling point at the dumpsites designated as A at the middle, B 50 meters to the west and C 50 meters to the east from the middle, and control. Values are means double replicates \pm standard

\begin{tabular}{llll}
\multicolumn{4}{c}{ deviations. } \\
\hline Samples & $\mathrm{A}$ & $\mathrm{B}$ & $\mathrm{C}$ \\
\hline Control & $3.2 \pm 0.3 \times 10^{4}$ & $3.1 \pm 0.2 \times 10^{2}$ & $2.7 \pm 0.1 \times 10^{4}$ \\
Edaiken & $7.3 \pm 0.8 \times 10^{2}$ & $5.2 \pm 0.3 \times 10^{2}$ & $4.3 \pm 0.4 \times 10^{2}$ \\
Oba Market & $7.8 \pm 0.4 \times 10^{2}$ & $3.1 \pm 0.2 \times 10^{2}$ & $5.3 \pm 0.3 \times 10^{2}$ \\
New Benin Market & $1.1 \pm 1.1 \times 10^{3}$ & $4.1 \pm 0.1 \times 10^{2}$ & $4.1 \pm 0.8 \times 10^{2}$ \\
Satana Market & $6.0 \pm 0.9 \times 10^{2}$ & $6.1 \pm 0.3 \times 10^{2}$ & $3.3 \pm 0.5 \times 10^{2}$ \\
Ekiosa Market & $3.0 \pm 0.8 \times 10^{2}$ & $5.2 \pm 0.5 \times 10^{2}$ & $6.4 \pm 0.2 \times 10^{2}$ \\
\hline
\end{tabular}

The enzymatic activities of the soil samples are shown in Table 5. The values presented are mean of three designated distance for each sampling points. The study showed a statistically significant $(\mathrm{P}<0.05)$ increase in the enzyme activities of the enzymes in the soil samples from the dumpsites compared to the control.
Table 3: Identified Bacterial Isolates from Dumpsites Soil Samples and their Frequency of Occurrence $(\%)$

\begin{tabular}{ll}
\hline Bacterial Isolates & $\begin{array}{l}\% \text { frequency of } \\
\text { occurrence }\end{array}$ \\
\hline Acinetobacter Species & 15.6 \\
Micrococcus Species & 7.8 \\
Pseudomonas aeroginosa & 20.3 \\
Serratia Species & 7.8 \\
Bacillus subtilis & 14.8 \\
Klebsiella Species & 14.1 \\
Staphylococcus aureus & 8.6 \\
Arthrobacter Species & 3.9 \\
Escherichia coli & 3.9 \\
Streptococcus feacalis & 3.1 \\
\hline
\end{tabular}

Table 4: Identified Fungal Isolates from dumpsites Soil Samples and their Frequency f Occurrence (\%)

\begin{tabular}{ll}
\hline Fungi isolates & $\begin{array}{l}\text { \% frequency of } \\
\text { occurrence }\end{array}$ \\
\hline Aspergillus niger & 22.4 \\
Trichodermal species & 9.6 \\
Penicillum species & 16.8 \\
Fusarium Species & 8.0 \\
Mucor species & 20.0 \\
Saccharomyces species & 12.0 \\
Rhizopus species & 11.2 \\
\hline
\end{tabular}

However, the activities decreased with distance away from the middle 
of the dumpsite which had more concentration of waste materials.

Table 5: Enzyme Activity of Soil Samples forms the various sampling point at the dumpsites. Values are mean of three designated sampling points and standard deviation.

\begin{tabular}{lcccccc}
\hline Parameters & Control & $\begin{array}{c}\text { Ediaken } \\
\text { market }\end{array}$ & Oba market & $\begin{array}{c}\text { New Benin } \\
\text { market }\end{array}$ & $\begin{array}{c}\text { Satana } \\
\text { market }\end{array}$ & $\begin{array}{c}\text { Ekiosa } \\
\text { market }\end{array}$ \\
\hline Urease $(\mathrm{mg} / \mathrm{g} / 24 \mathrm{~h})$ & $6.40 \pm 0.00$ & $44.10 \pm 19.82$ & $74.87 \pm 5.57$ & $69.77 \pm 29.88$ & $97.90 \pm 14.93$ & $58.73 \pm 7$. \\
Acid Phosphatase $(\mu \mathrm{mole} / \mathrm{g})$ & $1.60 \pm 0.0$ & $1.23 \pm 0.21$ & $1.10 \pm 0.36$ & $1.60 \pm 0.50$ & $0.97 \pm 0.42$ & $0.97 \pm 0.12$ \\
Alk. Phosphatase $(\mu \mathrm{mole} / \mathrm{g})$ & $1.50 \pm 0,00$ & $0.83 \pm 0.35$ & $0.77 \pm 0.07$ & $0.60 \pm 0.30$ & $1.03 \pm 0.57$ & $0.73 \pm 0.42$ \\
Dehydrogenase $(\mathrm{mg} / \mathrm{g} / 6 \mathrm{~h})$ & $4.10 \pm 0,00$ & $15.50 \pm 10.91$ & $23.70 \pm 16.3$ & $21.87 \pm 11.05$ & $12.83 \pm 0.96$ & $11.50 \pm 5$. \\
Peroxidase $(\mu \mathrm{mol} / \mathrm{h} / \mathrm{g})$ & $0.37 \pm 0.04$ & $2.67 \pm 0.91$ & $3.63 \pm 1.28$ & $4.07 \pm 0.60$ & $1.20 \pm 0.69$ & $1.20 \pm 0.20$ \\
Catalase $(\mu \mathrm{mol} / \mathrm{h} / \mathrm{g})$ & $<0.01$ & $0.02 \pm 0.01$ & $0.02 \pm 0.01$ & $0.03 \pm 0.01$ & $0.03 \pm 0.01$ & $0.02 \pm 0.01$ \\
\hline
\end{tabular}

Dehydrogenase $(23.70 \pm 16.32 \mathrm{mg} / \mathrm{g} / 6 \mathrm{~h})$ and Urease $(97.90 \pm 14.93 \mathrm{mg} / \mathrm{g} / 24 \mathrm{~h})$ had the highest activity at Oba and Satana market respectively. However, the activities decreased with distance away from the middle of the dumpsite which had more concentration of waste materials. Dehydrogenase $(23.70 \pm 16.32 \mathrm{mg} / \mathrm{g} / 6 \mathrm{~h})$ and Urease $(97.90 \pm 14.93$ $\mathrm{mg} / \mathrm{g} / 24 \mathrm{~h}$ ) had the highest activity at Oba and Satana market respectively.

Analysis of this work showed an increase in the activities of dehydrogenase, urease, peroxidase and catalase compared to the control. On the other hand alkaline and acid phosphatase was less sensitive to the pollution. High activity of Soil dehydrogenase observed in this work could be as a result of the high microbial activity in the samples.

This observation is in agreement with McCarthy et al., (1994), who observed high levels dehydrogenase enzyme in soils polluted with pulp and paper mill effluents. However, the work is in contract with Leo et al., (2014) who observed low levels of dehydrogenase activity.

This difference could be due to the type of soil contaminant examined as Leo et al., (2014) had worked on soil polluted with agrochemicals.

The increase in the activity of urease in the test samples could be attributed to the nature and type of waste deposited at these dumpsites which may contain lots of urea or urea containing components that encourages the growth of microbial species that produces greater quantity of the enzyme. Increase catalase activity observed in this study could be as a result of the increase in the dehydrogenase activity and microbial biomass while the increase in hydrogen peroxidase activities may be attributed to an increase in aerobic microbial activities in the test samples analyzed.
The physicochemical properties observed in this study are shown in Table 6 below. The various sampling point at the dumpsites and control sites all had an acidic $\mathrm{pH}$ with the highest $\mathrm{pH}$ (6.23) recorded at Satana market, Ekiosa market and control dumpsites while the lowest $\mathrm{pH}$ (5.60) was at New Benin market dumpsites. This could be as a result of the activities of nitrifying bacterial present in the soil. The nitrogen content of the soil samples was higher in the samples from the dumpsites than in the control samples with the highest concentration $(0.33 \pm$ $0.15 \%$ ) of nitrogen recorded at New Benin market dumpsite and the lowest concentration $(0.10 \pm 0.00$ $\%)$ at the control. phosphorus showed the same trend as nitrogen having its highest concentration $(7.67 \pm$ $0.87 \%)$ at Edaiken market and its lowest $(3.30 \pm 0.00$ $\%)$ at the control site.

Samples from the various sampling point had high amount of sand compared to clay and slit, Ekiosa market had the highest amount of sand $(85.93 \pm 4.67$ $\%)$ among the various dumpsites while New Benin market had the lowest amount of sand $(72.20 \pm 4.11$ $\%)$. Soil texture plays an important role in improving the cation exchange capacity (CEC) of the soil and therefore capacity to hold major and minor nutrients (Omar, 2015). The concentration of heavy metals in the soil samples from the various sampling point was at trace amount although iron had a significant increase when compared to the control.

The low concentrations of these trace metals in the analyzed soils could be the result of an interplay of several factors which include; the acidic $\mathrm{pH}$ and sandy nature of the soils which can result in the increased mobilization, precipitation and infiltration of these heavy metals in the soils (Osazee et al., 2013). 
Table 6: Physicochemical properties of soil samples from the various sampling point at the dumpsites. Values are mean of three designated sampling points and standard deviation ND - Not determined.

\begin{tabular}{|c|c|c|c|c|c|c|}
\hline Parameters & Control & $\begin{array}{c}\text { Ediaken } \\
\text { market }\end{array}$ & $\begin{array}{c}\text { Oba } \\
\text { market }\end{array}$ & $\begin{array}{c}\text { New Benin } \\
\text { market }\end{array}$ & $\begin{array}{l}\text { Satana } \\
\text { market }\end{array}$ & $\begin{array}{c}\text { Ekiosa } \\
\text { market }\end{array}$ \\
\hline $\mathrm{pH}$ & $6.23 \pm 0.25$ & $5.83 \pm 0.55$ & $5.73 \pm 0.93$ & $5.60 \pm 0.17$ & $6.23 \pm 0.25$ & $6.23 \pm 0.35$ \\
\hline Elect conductivity $(\mu \mathrm{S} / \mathrm{cm})$ & $21.37 \pm 0.7$ & $65.60 \pm 4.77$ & $84.17 \pm 7.0$ & $67.30 \pm 5.22$ & $86.10 \pm 5.64$ & $38.70 \pm 3.11$ \\
\hline Total organic carbon $(\%)$ & $0.60 \pm 0.00$ & $2.33 \pm 1.16$ & $2.73 \pm 0.40$ & $2.83 \pm 0.86$ & $2.40 \pm 1.32$ & $2.13 \pm 0.25$ \\
\hline Nitrogen $(\%)$ & $0.10 \pm 0.00$ & $0.20 \pm 0.10$ & $0.20 \pm 0.10$ & $0.33 \pm 0.15$ & $0.20 \pm 0.00$ & $0.13 \pm 0.6$ \\
\hline Phosphorus (\%) & $3.30 \pm 0.00$ & $7.67 \pm 0.87$ & $7.03 \pm 3.00$ & $6.93 \pm 3.96$ & $5.67 \pm 3.49$ & $4.47 \pm 3.75$ \\
\hline Sand $(\%)$ & $90.60 \pm 0.0$ & $78.40 \pm 1.81$ & $75.83 \pm 3.9$ & $72.20 \pm 4.11$ & $74.77 \pm 11.54$ & $85.93 \pm 4.67$ \\
\hline Slit $(\%)$ & $5.97 \pm 0.06$ & $5.93 \pm 0.76$ & $6.80 \pm 2.52$ & $8.27 \pm 1.88$ & $9.03 \pm 4.24$ & $3.97 \pm 1.37$ \\
\hline Clay $(\%)$ & $3.50 \pm 0.00$ & 15.70. 1.91 & $17.37 \pm 1.6$ & $19.43 \pm 4.45$ & $16.20 \pm 7.36$ & $9.97 \pm 3.21$ \\
\hline Calcium (meq/100g) & $1.70 \pm 0.00$ & $1.57 \pm 0.64$ & $2.37 \pm 1.50$ & $1.47 \pm 0.64$ & $1.10 \pm 0.70$ & $0.90 \pm 0.51$ \\
\hline Magnesium (meq/100g) & $0.90 \pm 0.00$ & $0.83 \pm 0.06$ & $1.30 \pm 0.61$ & $0.73 \pm 0.12$ & $0.57 \pm 0.21$ & $0.37 \pm 0.21$ \\
\hline Potassium (meq/100g) & $0.60 \pm 0.00$ & $0.40 \pm 0.10$ & $0.53 \pm 0.06$ & $0.40 \pm 0.10$ & $0.27 \pm 0.15$ & $0.23 \pm 0.06$ \\
\hline Sodium (meq/100g) & $0.20 \pm 0.00$ & $0.33 \pm 0.12$ & $0.63 \pm 0.15$ & $0.43 \pm 0.15$ & $0.30 \pm 0.10$ & $0.13 \pm 0.06$ \\
\hline Iron $(\mathrm{mg} / \mathrm{kg})$ & $0.80 \pm 0.00$ & $31.87 \pm 5.11$ & $40.67 \pm 7.7$ & $33.57 \pm 10.22$ & $16.13 \pm 3.08$ & $10.63 \pm 6.45$ \\
\hline Zinc (mg/kg) & $0.10 \pm 0.00$ & $1.43 \pm 1.01$ & $1.10 \pm 0.36$ & $1.53 \pm 1.02$ & $0.80 \pm 0.23$ & $0.70 \pm 0.36$ \\
\hline Copper (mg/kg) & $0.01 \pm 0.00$ & $0.57 \pm 0.15$ & $0.80 \pm 0.10$ & $0.70 \pm 0.26$ & $0.27 \pm 0.23$ & $0.30 \pm 0.00$ \\
\hline Lead (mg/kg) & $<0.01$ & $0.90 \pm 0.12$ & $1.23 \pm 0.17$ & $0.97 \pm 0.13$ & $0.13 \pm 0.06$ & $0.05 \pm 0.01$ \\
\hline cadmium (mg/kg) & ND & $0.08 \pm 0.04$ & $0.10 \pm 0.00$ & $0.06 \pm 0.03$ & $0.02 \pm 0.01$ & ND \\
\hline
\end{tabular}

Conclusion: There is no sanitary landfill in Benin City hence, indiscriminate disposal of untreated waste may not only poses human health risk but can also constitute a major environmental risk. However, despite the positive impact of the waste on the soil microflora and enzymatic activities, effort should be made in the treatment of waste before disposal as a measure to reduce health hazards associated with dumping of waste.

Acknowledgements: The authors would like to appreciate the Department of Microbiology, University of Benin, Benin City for providing the materials and support for this work.

\section{REFERENCES}

Abduls-Salem, N (2009). Assessment of heavy metal pollution in Dump sites in Ilorin metropolis. Ethi. J. Environ. Stud. Manag. 2(2): 92 - 99.

Agunwamba, JC (1998). Solid waste management in Nigeria: Problems and issues. J. Environ. Manag. 22: 849-856.

Alef, K; Nannipieri, P (1995). Methods in Applied Soil Microbiology and Biochemistry. Academic Press, London.

Cassida, LE; Kelvin, JO; Sntoro, D (1964). Soil dehydrogenase activity. J. Soil Sci. 98: 371- 374.

Constanza, R; Norton, BG; Haskell BD; (1992). Ecosystem Health: New Goals for Environmental Management. Island Press, Washington D.C.
Dick, RP (1997): Soil Enzyme Activities as Integrative Indicators of Soil Health. - In: Pankhurst, CE; Doube, BM; Gupta, VVSR (eds.) Biological Indicators of Soil Health, CABI Publishing.

Glanz, JT; (1995). Saving our soil: Solutions for sustaining Earth's vital resources. Johnson Books, Boulder, Colorado.

Grantina, L; Seile, E; Kenigsvalde, K; Kasparinskis, R; Tabors, G; Nikolajeva, V; Jungerius, P; Muiznieks, I (2011). The influence of the Land use on abundance and diversity of soil fungi: comparison of conventional and molecular methods of analysis. Environ. Exp. Biol. 9: 9 21.

Holt, JG; Krieg, NR; Sneath, PHA (1989). Bergey's Manual of Determinative Bacteriology (Vol. 4) Cambridge University Press London.

Kalra, Y. P. and Maynard, D. G. (1991). Methods Manual for Forest Soil and Plant Analysis. Micromedia Limited, Canada.

Larone, B.H. (1986). Important Fungi: A Guide to identification, Harper and Row Publishers, Hagerstown, Maryland.

Leo, OE; Emmanuel, IA; Victor, CU; Ositadinm, UC; Amadike, E (2014). Evaluation of physicochemical properties, microbial loads and enzymes activity studies of agrochemicals on the Imo-River basin farm in Imo State Nigeria. Int. J. Cur. Microbiol/ Appl. Sci. 3(2): 776-786. 
McCarthy, GW; Siddaramappa, R; Reight, RJ; Coddling, EE; Gao, G (1994). Evaluation of coal combustion by-products as soil liming materials: Their influence on soil $\mathrm{pH}$ and enzyme activities. Biol. Fert. Soils. 17: 167-17.

Obire, O; Nwabueta, O; Adue, SBN (2002). Microbial community of a waste dump site. $J$. Appl. Sci. Environ. Manag. 6 (1): 78 - 83.

Omar, AA (2015). Determination of macro and micronutrients levels in organic manure soils and irrigation water. J. Nat. Sci. Res. 3(2): 41-49

Onyeonwu, RO (2000). Manual for Waste/Wastewater, Soil/ Sediment, Plant and Fish analysis. MacGill Environmental Research Laboratory Manual. Benin City.

Osazee, OJ; Obayagbona, ON; Daniel, EO (2013). Microbiological and physicochemical analyses of top soils obtained from four municipal waste dumpsites in Benin City, Nigeria. Int. J. Microbiol. Mycol. 1 (1): 23 - 30

Pankhurst, CE; Doube, BM; Gupta, VVSR (1997). Biological indicators of Soil Health. In: Pankhurst, CE; Doube, BM; Gupta, VVSR (ed) Biological indicators of Soil Health, CAB International, pp $419-435$.
Pasquini, M. W. and Harris, F. (2005). Effective use of resources: Urban waste ash and soil fertility in Jos Plateau, Nigeria. J. Environ. Manag. 37(1):17-29.

Radojevic, M. and Bashkin V. N. (1999). Practical Environmental Analysis. Cambridge: The Royal Society of Chemistry, p.466.

Tabatabai, MA (1997). Soil Enzymes: In: Pages, AC; Millers, RH; Kenny, DR (ed), Methods of Soil Analysis Part 2: Chemical and Microbiological Properties, Soil Science, Society of American. $\mathrm{p}$ 134-152.

Thorn, RG; Lynch, MDJ (2007). Fungi and Eukaryotic Algea. In: Eldor, AP ( $3^{\text {rd }}$ ed), Soil Microbiology, Ecology and Biochemistry, Academic press Elsevier p 145-162.

Utobo, EB; Tewari, L (2015). Soil Enzymes as Bioindicators of Soil Ecosystem Status. Appl. Ecol. Environ. Res. (13) 1: 147-169.

Williams, JO; Hakam, K (2016). Microorganisms associated with dump sites in Port Harcourt Metropolis, Nigeria. J. Ecol. Nat. Environ. 8(2): 9-12 